\title{
Evaluation of Two Highly Porous Microcrystalline Biphasic Calcium Phosphate-Based Bone Grafts for Bone Regeneration: An Experimental Study in Rabbits
}

\author{
Miguel Ángel Garcés-Villalá1* ${ }^{*}$, Sergio David Rico1, Sergio Gustavo Nazar1, \\ Mariano Escudero-Pinel1, Víctor Galván-Josa² ${ }^{2}$ José Luis Calvo-Guirado ${ }^{3}$ \\ ${ }^{1}$ Department of Implant and Biomaterial Research, Fundación Corazón de Jesús, San Juan, Argentina \\ ${ }^{2}$ Facultad de Matemática Astronomía y Física, Universidad Nacional de Córdoba, Córdoba, Argentina \\ ${ }^{3}$ Department of Oral Surgery and Implant Dentistry, Faculty of Health Sciences, Universidad Católica San Antonio de Murcia, \\ Murcia, Spain \\ Email: ^fundacioncorazondejesus@gmail.com, davidricoodonto@yahoo.com.ar, sergionazar66@hotmail.com, \\ escuderopinel@gmail.com,galvan@famaf.unc.edu.ar, jlcalvo@ucam.edu
}

How to cite this paper: Garcés-Villalá, M.Á., Rico, S.D., Nazar, S.G., Escudero-Pinel, M., Galván-Josa, V. and Calvo-Guirado, J.L. (2020) Evaluation of Two Highly Porous Microcrystalline Biphasic Calcium Phosphate-Based Bone Grafts for Bone Regeneration: An Experimental Study in Rabbits. Journal of Materials Science and Chemical Engineering, 8, 8-30.

https://doi.org/10.4236/msce.2020.86002

Received: May 21, 2020

Accepted: June 25, 2020

Published: June 28, 2020

Copyright $\odot 2020$ by author(s) and Scientific Research Publishing Inc. This work is licensed under the Creative Commons Attribution International License (CC BY 4.0).

http://creativecommons.org/licenses/by/4.0/ (c) (i) Open Access

\begin{abstract}
A biphasic bone grafting biomaterial based on a mixture of calcium phosphates and beta-tricalcium phosphate ( $\beta$-TCP) phases with high nanoporosity was synthesized. The synthesis route was based on calcium phosphate composition and the incorporation of glycolic acid as a pore former, giving a material composed of $97 \% \beta$-TCP and $3 \%$ calcium orthophosphates $\left(\mathrm{CaPO}_{4}\right)$. An in vitro study of the purity, microstructure, crystalline domain, and pores size for the material obtained was performed by SEM analysis as well as full structural characterization. The region of interest related to the surface was determined by the specific surface area measured with the BET method. In vivo evaluation of bone response was performed by implanting the new low-cost biphasic manufacturing material synthesized in this work, which was compared with a biphasic material of similar chemical and microstructural composition existing in the commercial market and with higher cost called Synergy Odontit ${ }^{\circledR}$ $\beta$-TCP. The materials were implanted separately into $5 \mathrm{~mm}$ diameter defects in the tibias of New Zealand White rabbits at 30, 60, and 90 days. The results obtained showed that the host tissue well accepted the new biphasic material; the presence of new bone formation was observed. A more complete resorption was observed for the new microcrystalline biphasic material compared to for a commercial $\beta$-TCP material.
\end{abstract}




\section{Keywords}

Microcrystalline, Beta-Tricalcium Phosphate, Ceramic Bone Graft, Glycolic Acid

\section{Introduction}

This template, Bone tissue is in constant formation and resorption called the remodeling process. It consists of the reabsorption of a certain amount of tissue carried out by osteoclasts, while, simultaneously, osteoblasts produce an osteoid matrix that is subsequently mineralized. This process takes place in small areas of the cortical or trabecular surface called "basic bone remodeling units" (basic multicellular units, BMUs) formed by osteoclasts, osteoblasts, preosteoblasts, and macrophages. In these units, the activation of osteoclasts first occurs at a specific place in the skeleton, which results in bone tissue resorption, and then and in the same place, osteoblasts are activated, forming new bone tissue [1] [2] [3]. Osteoclasts and osteoblasts exert their activities in the so-called bone remodeling compartments (BRCs), which are separated from the bone marrow cavity by a monolayer of flat cells. It has been shown that BRCs in their three-dimensional reality are part of a previously unrecognized anatomical microstructure, which involves microcapillaries, and there are communications between bone marrow niches and tissue surfaces in the process of remodeling [4].

Some osteoblasts are finally buried within the lagoons of a mineralized matrix. These cells are called osteocytes and are characterized by a striking star morphology, reminiscent of the dendritic network of the nervous system. Surface cells, osteoblasts, and osteoclasts are found on the bone surface, while osteocytes are inside the bone. Osteocytes are the most abundant cells of bone tissue (10 times more than osteoblasts). Its body is located inside osteoplasts or osteocytic lacunae, and cytoplasmic processes are arranged inside calcophoric ducts that are filled with an extracellular matrix (ECM). Osteocytes are organized forming a sync of interconnected cells through multiple cytoplasmic processes; they communicate through nexus junctions with each other and with the bone tissue surface cells along canaliculi, representing a unique structure. Osteoblasts, in turn, can communicate with bone marrow stroma cells, as they extend cell projections into endothelial cells within sinusoids. This large contact surface between osteocytes and the blood vessel wall throughout its path allows them to ensure oxygen and nutrients. When trauma to bone tissue occurs, the cessation of blood circulation causes hypoxia and necrosis of osteocytes that occur more than $0.1 \mathrm{~mm}$ from an intact capillary. Osteocytes also participate in the synthesis and mineralization of an osteoid matrix, but their main function is to control the modeling and bone remodeling by a mechanotransduction process, detecting mechanical loads through changes in the flow of interstitial fluid in canaliculi. The cyclic compression load promotes osteoblast differentiation. Consequently, compression on bone tissue produces deformations on osteocytic membranes that induce biochemical mod- 
ifications thereof. This allows these mechanosensory cells to detect the need for augmentation or reduction of bone tissue during the functional adaptation of the skeleton, the need for microlesion repair, and, in both cases, to transmit signals that lead to an appropriate response. Osteocytes constitute the final stage from the osteoblast line and are unable to renew [5] [6] [7]. A new study confirmed that autogenous bone tissue fragments generated during surgery (for example, in the preparation of an implant site), accelerate the formation of tissue by releasing a wide variety of growth factors from an ECM and cells contained within this matrix. Osteocytes, whether viable or in apoptosis, within such fragments are able to recruit osteoclasts to a bone remodeling site and support the formation of bone tissue on their surfaces. In addition, osteocytes within autogenous fragments are often able to repair interrupted canalicular networks to connect with other osteocytes or osteoblasts in the new bone tissue formed on the surfaces of fragments [8].

When an osseointegrated implant is placed or a graft is performed to increase the bone substrate before the insertion of implants, bone regeneration, which means the new bone tissue is identical to the pre-existing ones, is sought. A bone matrix must have suitable mechanical properties to provide structural support during bone growth, allowing vascular neoproliferation and consequently bone formation. Biodegradable or resorbable ceramics are ceramics that gradually degrade and replaced by reactive bone tissue, a process also known as bioabsorption [9]. Tricalcium phosphate (TCP) in its active forms and calcium sulfate hemihydrate (plaster of Paris) are part of this group. These types of bioceramics are superior, since they remain in the body only as long as their function is necessary, disappearing as tissues are regenerated. Its major drawback is that its resistance also decreases during the resorption process. Therefore, synchronization and balance control between scaffolding-material resorption and new bone tissue formation are crucial aspects for the success of bone tissue engineering [10] [11] [12].

Ceramics have been used as grafts for decades and are seen as a viable solution to the problem of bone loss. However, the challenge is to develop a biomaterial that mimics macro- and microstructures and can be part of the composition of bone tissue, so that it harmonizes locally with the host tissue and provides a biologically stable implant [13]-[18]. Calcium orthophosphates, such as beta-tricalcium phosphate ( $\beta$-TCP) and hydroxyapatite (HA), are the most commonly used resorbable bioceramics as synthetic bone tissue implants [19]. Currently, these $\mathrm{CaPO}_{4}$ are used combined in different proportions forming biphasic compounds that can improve their therapeutic performance [20] [21] [22].

Porosity is an essential factor that allows for the union between bioceramics and bone tissue, and interconnected porous structures allow for the penetration of vasculature into pores connecting mesenchymal stem cells (MSCs) and osteotropic agents. A larger contact area allows for a more significant contact and exchange relationship with the recipient bone tissue. Porous scaffolding must have 
a porosity higher than $50 \%$ with a recommended minimum pore size of $100 \mu \mathrm{m}$ [23] [24] [25], which is the same requirement for physiological Havers systems of bone tissue that have an approximate diameter greater than $100 \mu \mathrm{m}$. The minimum porosity necessary for the regeneration of a blood vessel is approximately 30 to $40 \mu \mathrm{m}$ to allow for the exchange of metabolic components and to facilitate the entry of blood vessels [26]. However, the average size of macropores and pore interconnections of more than $300 \mu \mathrm{m}$ induction provides bone neoformation, increasing the differentiation and proliferation of osteoblasts throughout scaffolding with mass oxygen transport and nutrient flow, also facilitating waste disposal [26] [27]. A significant impact on osteogenic response is microporosity (pore size $<10 \mu \mathrm{m}$ ), roughness of a pore wall, and macroporosity (pore size $>50 \mu \mathrm{m}$ ); all of them contribute to adsorption of osteoinductive proteins, ion exchange, and the formation of apatite similar to bone tissue by dissolution and reprecipitation [9] [28] [29].

Microporosity improves the load transfer between tissues and the hardness of a material. It also facilitates the material establishment of a continuous mechanosensory network [30]-[36]. Although increase in porosity and a larger pore size facilitate bone tissue growth, the structural integrity of the scaffold can be jeopardized and can adversely affect its mechanical properties if the porosity is very high at the same time. Therefore, manufactured scaffolds from biomaterials should not have high porosities $(>90 \%)$ in order to avoid compromising the structural and mechanical integrity before proper replacement by the newly formed bone tissue [37]. The small size of crystalline domains forms a smaller size of the microstructure of a surface that allows for a more significant contact stability and reaction at the interface between a grafted material and the host bone. The activation and adsorption of MSCs would support the intrinsic stimulation of the formation of new bone tissue to surfaces with nanometric topographic features [38] [39] [40]. Achieving a balance between resistance to deformation and porosity is vital to develop porous scaffolds with mechanical stability optimally. The pore structure of scaffolding is an essential consideration for vascularization, cell migration, and a better organization for cell growth and ECM production [41].

Previously, we presented a method to obtain a mixture of HA/ $\beta$-TCP by a chemical method [42]. The method is low-cost, because it uses technical grade precursors and the use of glycolic acid during the synthesis to provide a highly porous material without the need to use additional porogenic agents. This reduces manufacturing cost, which impacts marketing cost and expands the possibility of massive application of bone grafting. Using light microscopy, we made a comparative analysis of the distribution and activities of osteoblastic cells on biomaterials 30, 60, and 90 days after implantation. The present work takes a multimodal approach consisting of a study of the crystallinity, composition, and pore-volume, as well as compression testing, of this new material and its cellular biodegradation when used to fill critically sized bone defects in rabbit tibia, comparing its 
performance with those of a commercially available $\beta$-TCP graft material (Synergy Odontit ${ }^{\circledR}$; Buenos Aires, Argentina) [43] and unfilled control defects.

\section{Materials and Methods}

\subsection{Sample Preparation}

A biphasic $\beta$-TCP/CaPO ${ }_{4}$ mixture was obtained by using a technical-grade dust calcium phosphate tribasic with $34.0 \%-40.0 \%$ Ca basis (Sigma-Aldrich ${ }^{\circledR}$ Merck, Buenos Aires, Argentina), and an aqueous glycolic acid solution at a concentration of $70 \% \mathrm{~V} / \mathrm{V}$ with a $\mathrm{pH}$ value of 0.1 (DuPont ${ }^{\circledR}$, Wilmington, DE, USA). Glycolic acid was added to the powder at a concentration of $1 \mathrm{~mL} / \mathrm{g}$ in a glass vessel and continuously stirred $(20 \mathrm{rpm})$ for $10 \mathrm{~min}$. An exothermic reaction with a maximum temperature of $57.5^{\circ} \mathrm{C}$ was produced. Afterward, the sample was dried in a furnace (at $160^{\circ} \mathrm{C}$ for $8 \mathrm{~h}$ ) to evaporate the water excess. Then, the material is ground to break up agglomerates and sieved to obtain particle sizes of 650 $1250 \mu \mathrm{m}$. After that, the sample was heated at $500^{\circ} \mathrm{C}$ for $20 \mathrm{~min}$ under a $60^{\circ} \mathrm{C} / \mathrm{min}$ heating rate at atmospheric pressure. Then, the temperature was raised (with the same heating rate) up to $1150^{\circ} \mathrm{C}$, and the material was maintained at this temperature for three hours at atmospheric pressure and then for three more hours in a vacuum atmosphere. The last thermal treatment produced a solid-state reaction, which reduced $50 \%$ of the sample weight and transformed the material into the biphasic $\beta$-TCP/CaPO ${ }_{4}$ phase (ARG. GLICO $\beta$-TCP) (see in Figure $1(a)$ and Figure 1(b)).

\subsection{Material Characterization}

The microstructure of the material obtained was characterized by a Zeiss Sigma Field Emission-SEM (Carl Zeiss, Oberkochen, Germany), operated at $5 \mathrm{kV}$. XRD patterns were acquired in a Panalytical Empyrean Philips PW $3710 \mathrm{X}$-ray diffractometer in a $2 \theta$ range of $5^{\circ}-90^{\circ}$ (step size: $0.02^{\circ}$ ) with $\mathrm{Cu}-\mathrm{K} \alpha$ radiation at a voltage of $30 \mathrm{kV}$ and a current of $25 \mathrm{~mA}$ to determine the mineral phases present in both study materials. Patterns were quantified by the Rietveld method.

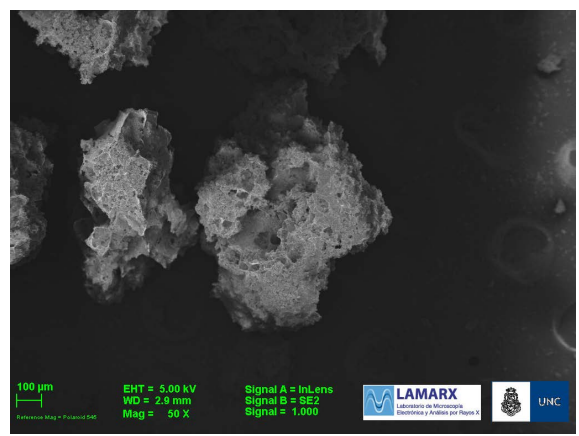

(a)

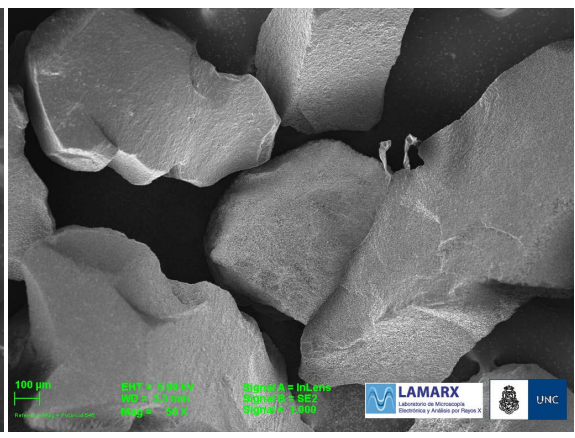

(b)

Figure 1. SEM images of biphasic materials particles used to fill critical size defects of tibia rabbits: (a) Granules of beta-tricalcium phosphate ( $\beta$-TCP) ARG. GLICO material; (b) Commercial Synergy Odontit ${ }^{\circledR} \beta$-TCP material (Buenos Aires, Argentina). 
The specific surface area (BET area) allowed obtaining the total area of the sample that was in contact with biological tissues and was determined by a DigiSorb 2600 Micromeritics micrometer surface area analyzer. For compression tests, the materials were compacted in the form of bars. The bars of the ARG. GLICO $\beta$-TCP and commercial Synergy Odontit ${ }^{\circledR} \beta$-TCP materials (Odontit Argentina, Buenos Aires, Argentina) were obtained by cold isostatic pressing at $200 \mathrm{MPa}$ for one hour, followed by sintering at $1000^{\circ} \mathrm{C}$ during the second hour with a temperature rise range of $5^{\circ} \mathrm{C} / \mathrm{min}$. The bars were cut into circular discs with a diameter $(D)$ of approximately $7.14 \mathrm{~mm}$ and a thickness $(t)$ of approximately 2.11 $\mathrm{mm}(t / D$ ratio: approximately 0.29$)$.

Strength was determined using compact disc diametral compression tests (DCDTs) following the procedures described in previous studies [44] [45]. Sixteen circular discs of each composition were placed between two stainless steel plates with their faces perpendicular to loading plates in a universal testing machine (MicroTest, Madrid, España). The load was applied at a machine frame travel speed of $0.5 \mathrm{~mm} / \mathrm{min}$.

For DCDT samples, the highest tensile force was uniform across the central part of the diametral plane of the samples, and the areas closest to the load withstood the compression. The compression ratio was smaller for more rigid samples. The fault occurred through the diametral plane, and the samples were broken into two similar pieces, corresponding to a drop in load in the load-displacement curves recorded during the tests. The maximum load before the fall was used to calculate the diametral force, $\sigma_{f}$ using Equation (1):

$$
\sigma_{\tau}=\frac{2 f}{\pi D \tau}
$$

The results of 16 valid tests were used to calculate Weibull parameters using the procedure of ENV-843-5 [46], which implies the simplest form of the Weibull function [47] shown as Equation (2):

$$
P_{f}=1-\exp \left[-\left(\frac{\sigma_{f}}{\sigma_{0}}\right) m\right]
$$

where $P_{f}$ is the probability of failure in the tension $\sigma_{f}, \sigma_{0}$ is the breaking stress, which is the maximum stress that the material endures before it is broken, corresponding to the tension at which the probability of failure is $63.2 \%$, and $\mathrm{m}$ is the Weibull module. The probability of failure was calculated using Equation (3):

$$
P_{f}=\frac{n-0.5}{N}
$$

where $N$ is the total number of specimens tested and $\mathrm{n}$ is the sample range in ascending order of fault voltage. This function of Weibull has been shown to adequately describe the distribution of the strengths of dense and porous materials (up to $60 \%$ by volume) [48] [49] [50]. 
The same analyses for microstructures, mineral phases detections, specific surface areas, and compression tests were completed for a control material (Sinergy Odontit ${ }^{\circledR} \beta$-TCP, Buenos Aires, Argentina) with the same evaluation conditions.

\subsection{Implantation Procedure}

The experimental study was carried out following the ethical principles for experimental animals research of Catholic University of Cuyo San Juan Argentina Institute of Bioethics (UCCSJ) San Juan October 102012 (Ref: Project M.A Garcés).

Fifteen New Zealand male rabbits of six months age weighted 3.1 - $3.6 \mathrm{~kg}$ were used in the study. The ARRIVE guidelines for animal experimentation were followed. The sample size per group was calculated at a statistical power of $80 \%$ and an error of $0.5 \%$. The group allocation in each tibia was randomly selected using the software Research Randomizer.

Rabbits were fed "Ad libitum" with solid food and water for adaptation in cages at $24^{\circ} \mathrm{C}$ and $50 \%$ humidity with a $12 / 12 \mathrm{~h}$ light/dark photoperiod [51]. Before the surgery, rabbits were anesthetized with Ketamine Hydrochloride (Ketalase ${ }^{\circledR}$ ) (body weight (BM): $50 \mathrm{mg} / \mathrm{kg}$ ), IM, and chlorpromazine (Ampliactil ${ }^{\circledR}$, Sanofi, Aventis, Buenos Aires, Argentina) (BW: $10 \mathrm{mg} / \mathrm{kg}$ ), IM [52]. Antibiotic prophylaxis was performed with amoxicillin (Amoxidal ${ }^{\circledR}$, Roemmers, Buenos Aires, Argentina) with a BW of $15 \mathrm{mg} / \mathrm{kg}$, administered in single doses and $30 \mathrm{~min}$ before the intervention. The two hind legs were shaved, and a full-thickness incision was made to expose the proximal antero-internal area of each tibia. Two critical defects (holes with $5 \mathrm{~mm}$ in diameter) were made in each of tibias, the graft filled one of them, and the other was kept as a control (Figure 2).

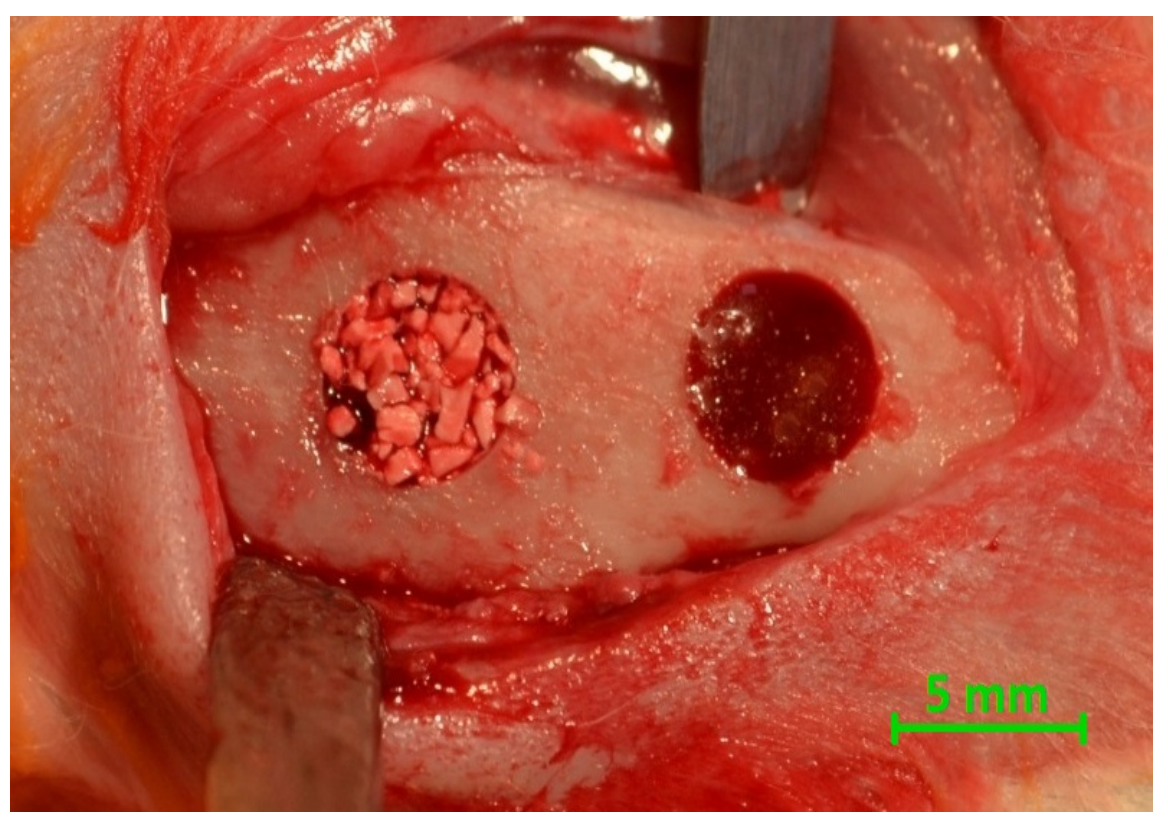

Figure 2. Defects created in a tibia filled with $0.176 \mathrm{~cm}^{3}$ of the ARG. GLICO $\beta$-TCP material in the present work (left) and unfilled for controls (right). 
The animal surgery was done on each of the legs, in the proximal anterointernal area of each tibia to place the graft. Five milimeters bone defects were filled with substitute materials previously sterilized in a dry heat stove at $170^{\circ} \mathrm{C}$ for two hours and then stored in phosphate-buffered saline (PBS) before placement. Subsequently, the wound was carefully closed with continuous interlaced resorbable suture of Glicosorb ${ }^{\circledR}$ polyglycolic acid 3/0, starting with the periosteum and a deep muscular plane. The cutaneous plane was also faced employing a continuous suture entwined with Silk 3/0. Finally, after washing the surgical wound with a physiological serum, a Rifocina ${ }^{\circledR}$ rifampicin spray (Sanofi-Aventis, Buenos Aires, Argentina) was applied. Postoperative pain and inflammation of rabbits were controlled with the administration of Helenil ${ }^{\circledR}$ ketoprofen (Roux-Ocefa, Buenos Aires, Argentina) (BW: $1000 \mu \mathrm{g} / \mathrm{kg}$ ) every 24 hours, one hour before the intervention and for three days [53]. Two perforations were made in each of tibiaes of each rabbit for a total of 60 perforations. In one tibia, the synthesized material was placed, and one empty defect was left, whereas in the other tibia, a commercial bone substitute was applied to one defect and the other one was left empty (Figure 3 ). The volume ( $V$ ) of the bone substitute that was placed in cylindrical bone defects with a critcial size was calculated using the following volume equation: $V=\pi \mathrm{r}^{2} h=3.14 \times 2.5^{2} \times 9 \mathrm{~mm}^{3}$, which was $176 \mathrm{~mm}^{3}$ equaling to $0.176 \mathrm{~cm}^{3}$. No filling $(\mathrm{n}=30)$ was applied in the control group, Sinergy Odontit ${ }^{\circledR}$ $\beta$-TCP (Odontit Argentina, Buenos Aires, Argentina) $(\mathrm{n}=15)$ was used in test A, and ARG. GLICO $(\mathrm{n}=15) \beta$-TCP was used in test B. Day 0 (zero) was considered at the time of surgery. After 30,60 , and 90 days of healing, five rabbits were sacrificed at each of experimental times under anesthesia by administering an intravenous sodium thiopental overdose obtaining a sample of 10 tibiaes at a time.

\subsection{Histological Analysis}

After sacrifice, tibias were extracted, soft tissues were removed to expose the rabbit's tibia, and bone blocks containing experimental areas were obtained with an oscillating saw. The blocks were fixed in a 10\% formaldehyde solution at $\mathrm{pH}$ 7.0.

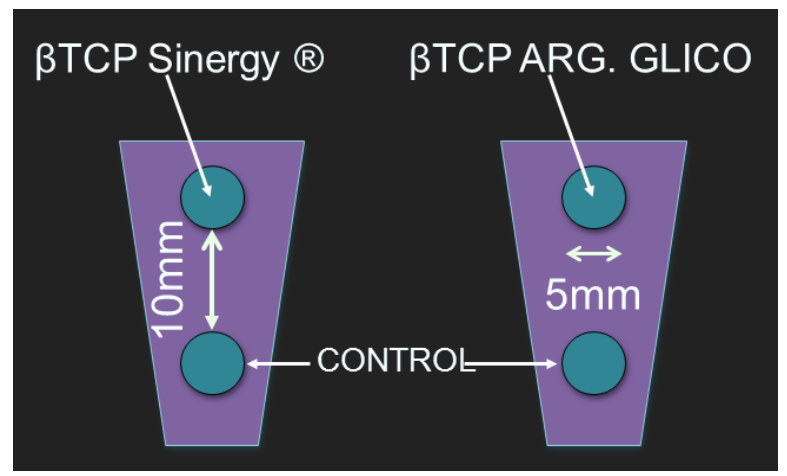

Figure 3. Surgical protocol in both tibias. Critical defects with a diameter of 5 millimeter were made in both tibias; 10 millimeters of separation was left between the perforations in one defect material implanted and the other left as a control without filling. 
Bone samples were demineralized for five weeks in a 10\% EDTA solution ( $\mathrm{pH} 7.4$ ). Then, the pieces were dehydrated in a gradient of ascending alcohol (60\% - 100\%) and processed for later inclusion in paraffin. Next, samples were sectioned in $5 \mu \mathrm{m}$ thickness with a microtome. Finally, the samples were stained with hematoxylin and eosin to perform the histomorphometric analysis by optical microscopy. Histological images were obtained with an Olympus BX 50 fluorescence microscope (Leica, Wetzlar, Germany) connected to a Sony CCD-IRIS digital camera (Sony Global Eng Net, Argentina) equipped with lenses for detailed evaluation and morphometric measurement. Measurements in the area of a newly formed bone in the defect were obtained using Image-Pro Plus software version 4.5.2 (Media Cybernetics Inc, Rockville, Maryland, USA). In histological images, osteoblasts were seen aligned in contact with trabecular bone, while osteocytes were scattered on the surface of bone trabeculae. For this reason, osteoblasts were measured in millimetres, and osteocytes were measured in square millimeters. Osteoblasts and osteocytes can be differentiated and counted perfectly with a $40 \times$ optical microscope. The number of osteocytes per surface $\left(\mathrm{mm}^{2}\right)$ was calculated, and the osteoblasts were linear $(\mathrm{mm})$ using 30 images at a magnification of $40 \times$ in total, that is, 10 images for each time of the study. Biomaterial particles remaining at the end of the study (90 days) were observed and measured with a 1.3 MP Motic camera considering the area they occupied in a reference region. Images were captured with a $10 \times$ objective and calibrated with a circle of $150 \mu \mathrm{m}$ using the Motic Images Plus 2.0 ML program (Laboquimia, La Rioja, Spain).

A two-way ANOVA test was used for the statistical analysis of histomorphometric data, (group and stage), and to evaluate the differences between specific means, post hoc tests (Tukey DHS) were performed. For all tests, the value of statistical significance was set at $\mathrm{p}<0.05$. Data were processed with the statistical software package SPSS v.20 (IBM-SPSS Inc., Chicago, IL, USA). The researchers of this work were blinded, that is, they were unaware of the intervention the groups under study were receiving.

\section{Results}

\subsection{Material Characterization}

The physical structures at the micrometer scale of the material synthesized and the commercial $\beta$-TCP can be observed in Figure 4.

Particles corresponding to the ARG. GLICO $\beta$-TCP had irregular forms with spherical edges, associated with a high macroporosity. In addition, the specific surfaces of these particles were microcrystalline and concave. The nanostructures of the material synthesized and the commercial $\beta$-TCP can be seen in Figure 5. Even when the shapes of the subunits were similar for both samples, the size of the commercial sample was almost twice that of the synthesized material.

The $\mathrm{Ca} / \mathrm{P}$ ratios, estimated by quantification of energy-dispersive $\mathrm{X}$-ray spectra, were 1.5 and 1.6 for the synthesized and commercial $\beta$-TCP samples, respectively. XRD patterns of the material synthesized and the corresponding Rietveld 


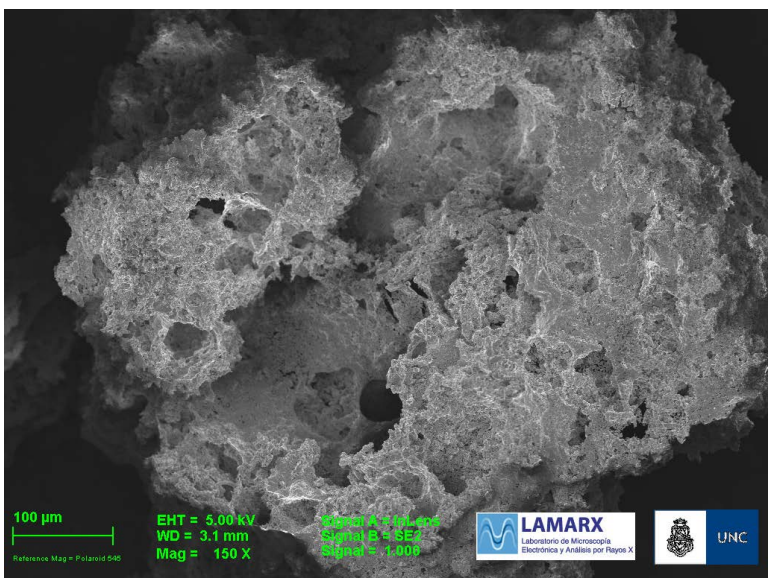

(a)

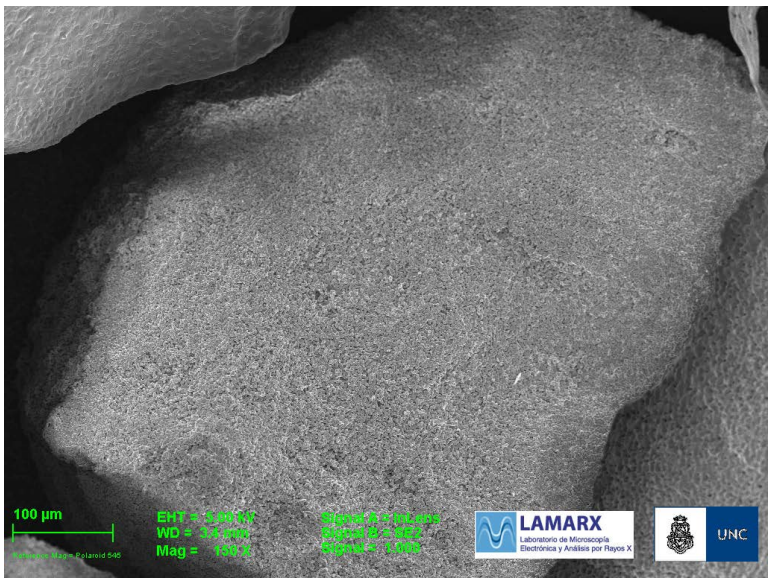

(b)

Figure 4. SEM micrographs at a magnification of 150×: (a) ARG. GLICO $\beta$-TCP having irregular shapes and rounded edges and macropores between 150 and $500 \mu \mathrm{m}$; (b) Sinergy Odontit ${ }^{\circledR} \beta$-TCP (Buenos Aires, Argentina) having regular shapes and straight edges and no macropores.

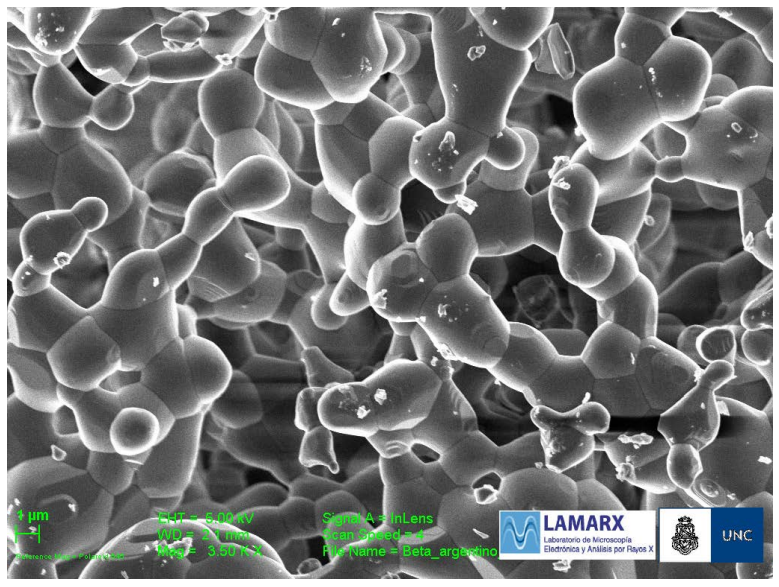

(a)

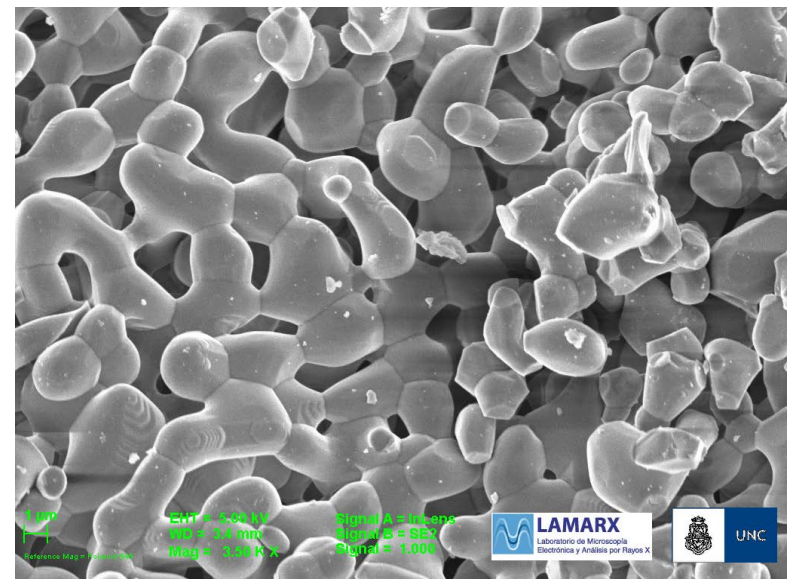

(b)

Figure 5. SEM photomicrographs at a magnification of 3500×: (a) ARG. GLICO $\beta$-TCP. Micropores with sizes between 1 and 9 $\mu \mathrm{m}$ were observed and had a smaller surface microstructure; (b) commercial Sinergy Odontit ${ }^{\circledR} \beta$-TCP (Buenos Aires, Argentina). Micropores with sizes between 1 and $4 \mu \mathrm{m}$ and a larger surface microstructure were observed.

refinement are shown in Figure 6. No remains of the starting materials were observed, and the mass concentrations of the detected phases were $97 \% \beta$-TCP, $1.04 \%$ dicalcium phosphate, and $1.89 \%$ phosphate tetra calcium oxide.

The phases identified for commercial grafting were $90 \% \beta$-TCP, $8.68 \%$ dicalcium phosphate, and $1.29 \%$ phosphate tetra calcium oxide shown in Figure 7. The Rietveld method allowed obtaining structural refinement, in addition to the phase concentrations of the analysis, the parameters of the crystalline cell, and the size of the crystals. The crystalline sizes obtained in the refinement were 120 $\mathrm{nm}$ for the commercial Sinergy Odontit ${ }^{\circledR} \beta$-TCP (Buenos Aires, Argentina) and $67 \mathrm{~nm}$ for the ARG. GLICO $\beta$-TCP phase, which represented almost twice the domain size $(1.79 \mathrm{~nm})$. These crystalline domain sizes represented the mean value of coherent domains for diffraction, and they did not coincidence with the sub- 
unit sizes observed by SEM, since these subunits were composed by many of the crystallites domains. A detailed study on diffraction of biphasic ceramics by X-ray techniques can be found elsewhere [42].

Regarding the mechanical tests of the biphasic sample synthesized here, the parameters of the Weibull force distribution, determined by diametral disk compression, were as follows: modulus, $\mathrm{m}=5.4$, and $\sigma_{0}=4.9 \mathrm{MPa}(80 \%$ confidence interval: $\left.\mathrm{m}=5.4-6.0, \sigma_{0}=4.6-5.3\right)$, whereas for the commercial $\beta$-TCP $\mathrm{m}=6.7$ and $\sigma_{0}=5.9 \mathrm{MPa}\left(80 \%\right.$ confidence limit: $\left.\mathrm{m}=6 / 7-7 / 3, \sigma_{0}=6.2-5.6\right)$. The Weibull distribution calculated using the specified Weibull module and the characteristic resistance is shown in Figure 8 together with the experimental data. The lower and upper limits for Weibull parameters are summarized in Table 1.

The total porosity was calculated by comparing the theoretical density $\rho c$ of a $\mathrm{CaPO}_{4}-\beta$-TCP mixture with the measured density $\rho \mathrm{m}$ and represented the fraction of volume occupied by pores. The porosity values obtained from this method were $80 \%$ for the present biphasic sample and $50 \%$ for the commercial sample. The specific surface areas by the BET method were $3.98 \pm 0.05 \mathrm{~m}^{2} / \mathrm{g}$ for the material studied obtained and $1.50 \pm 0.05 \mathrm{~m}^{2} / \mathrm{g}$ for the commercial material.

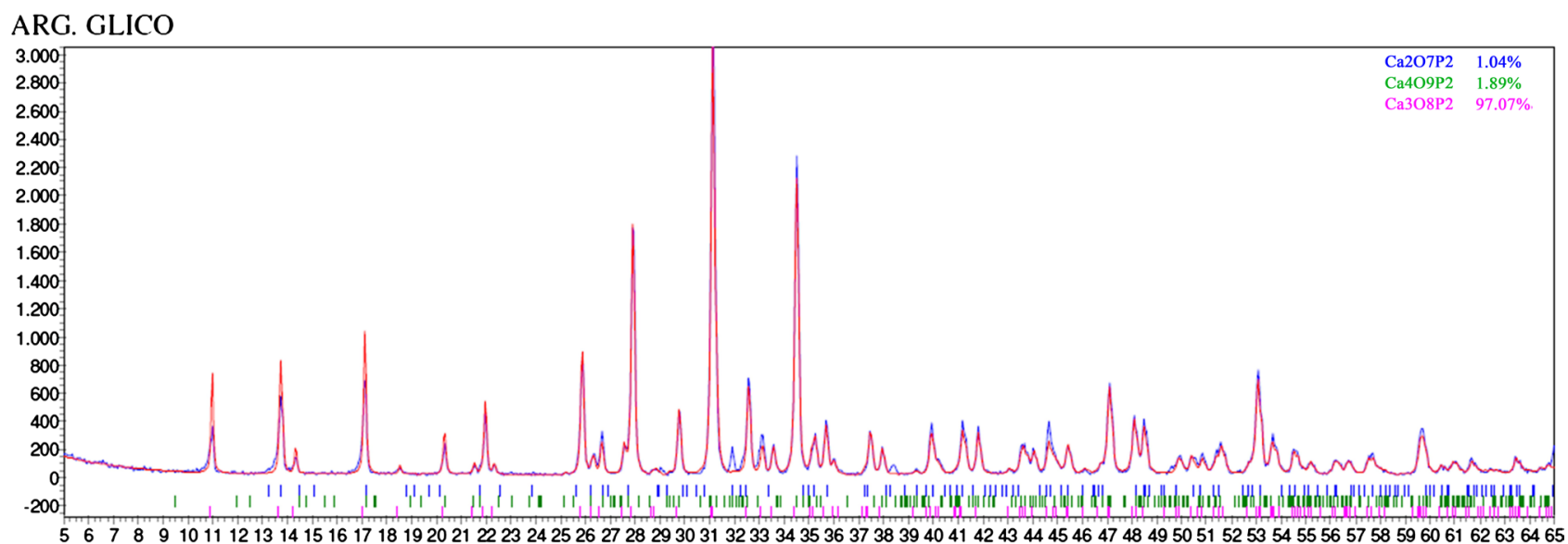

Figure 6. XRD pattern and Rietveld analysis of the ARG. GLICO $\beta$-TCP.

\section{ODONTIT}

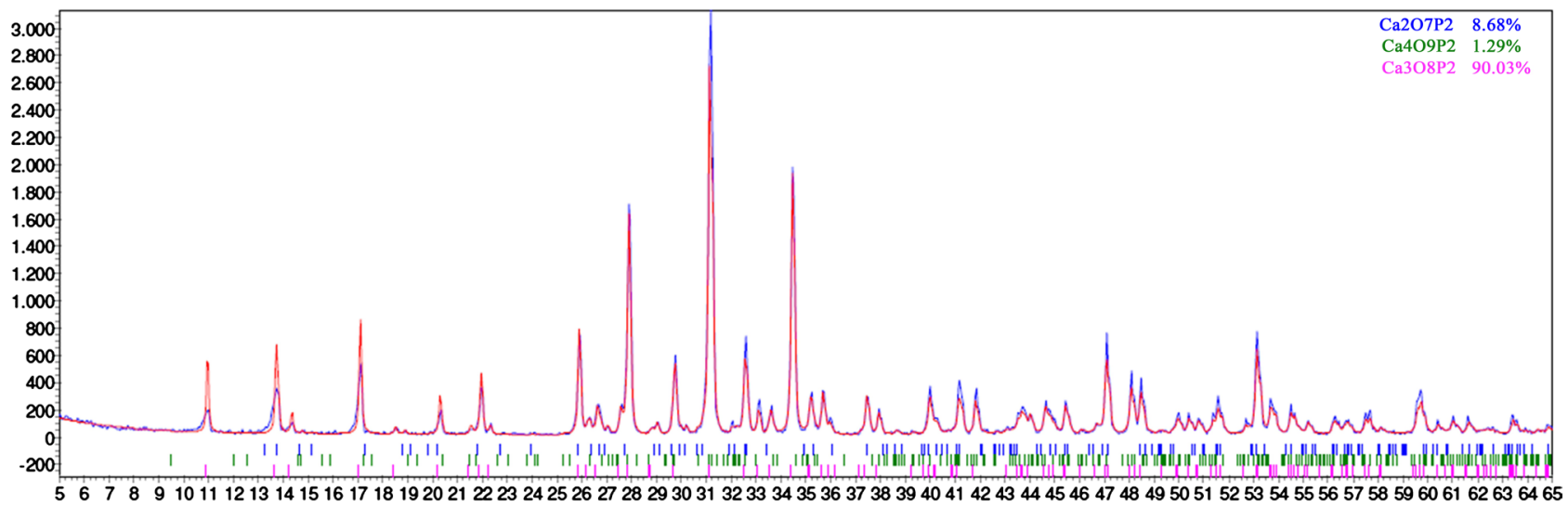

Figure 7. XRD pattern and Rietveld analysis of the commercial Sinergy Odontit ${ }^{\circledR} \beta$-TCP (Buenos Aires, Argentina). 


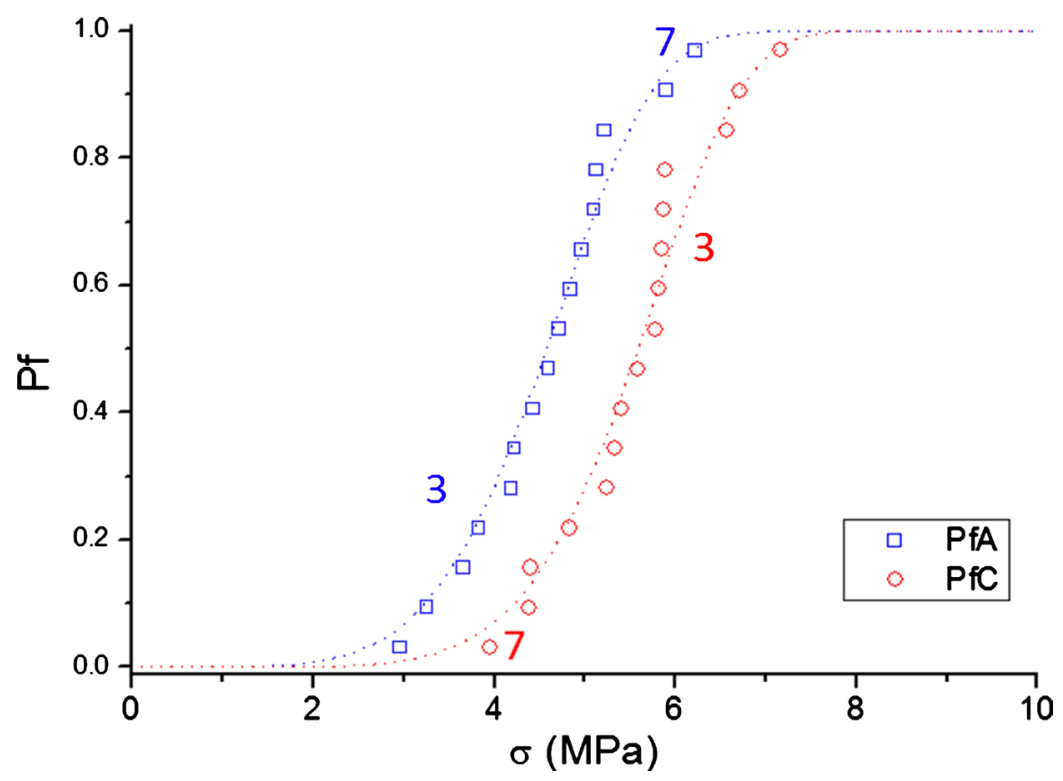

Figure 8. Weibull distributions (indicated by lines) calculated using the determined Weibull parameters (Table 1) and experimental data (indicated by points). Pf: probability of failure.

Table 1. Weibull parameters following the procedures of ENV 843-5 with an 80\% confidence limit. Du and Dl represent upper and lower limits for the Weibull distribution. $\mathrm{Cu}$ and $\mathrm{Cl}$ represent upper and lower limits of a characteristic resistance, $\sigma_{0}$. Distribution calculated using the unbiased values of Wexp and Wcorr.

\begin{tabular}{cccccccc}
\hline Material & $W_{\text {exp }}$ & $W_{\text {corr }}$ & $D_{u}$ & $D_{I}$ & $\sigma_{0}(\mathrm{MPa})$ & $C_{u}$ & $C_{l}$ \\
\hline Comercial $\beta$-TCP & 7.3 & 6.7 & 8.9 & 5.2 & 5.9 & 6.2 & 5.6 \\
ARG. GLICO $\beta$-TCP & 6.0 & 5.4 & 7.2 & 4.2 & 4.9 & 5.3 & 4.6 \\
\hline
\end{tabular}

\subsection{In Vivo Study}

The experimental areas healed uneventfully along the entire experimental periods. Considering the critical size of the wound and the effect of the biomaterial evaluated, only the repair at the level of the defect could be clearly observed from cortical walls in the histological sections 90 days after the study. However, the advantages of using a graft material for filling bone defects can be seen in Figure 9, which shows healing in a cortical area with greater amounts of bone trabeculae than in an unfilled defect, regardless of a graft material employed.

Figure 10 shows histomorphometric images on the decalcified sections at 30 , 60 , and 90 days after implantation of the ARG. GLICO $\beta$-TCP and the commercial $\beta$-CTP. The corresponding quantitative analysis is shown in Figure 11.

After 30 days, the formation of bony trabeculae of lamellar bone tissue was observed in the graft areas of both biomaterials. Hematopoietic marrows and adipocytes were found in the area of unfilled boreholes, but no trabeculae were observed. In the biphasic material presented here, the vascularization of the porous network of the biomaterial was observed through the homogeneous formation of a new vessels network that occupied a substantial extension of the graft, and some trabeculae penetrated inside. 


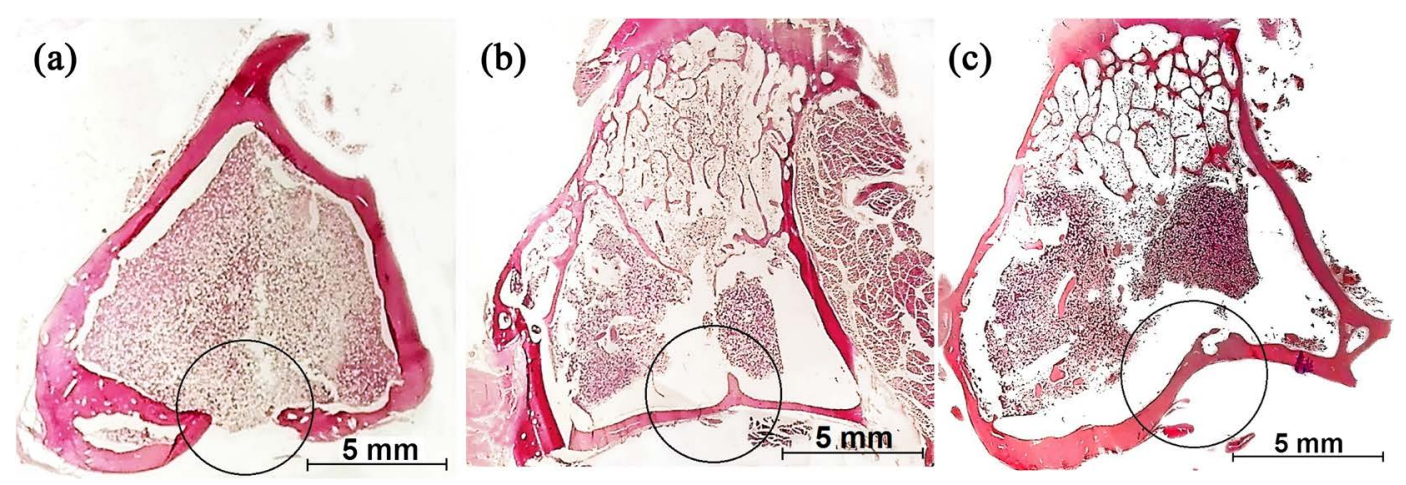

Figure 9. Cross-sectional photomicrographs of a tibia at 90 days in the cortical zone of a critical defect: (a) control without a bone cortical wall in the area of critical defects and abundant hematopoietic marrows;

(b) ARG. GLICO $\beta$-TCP; and (c) Sinergy Odontit ${ }^{\circledR} \beta$-TCP (Buenos Aires, Argentina).

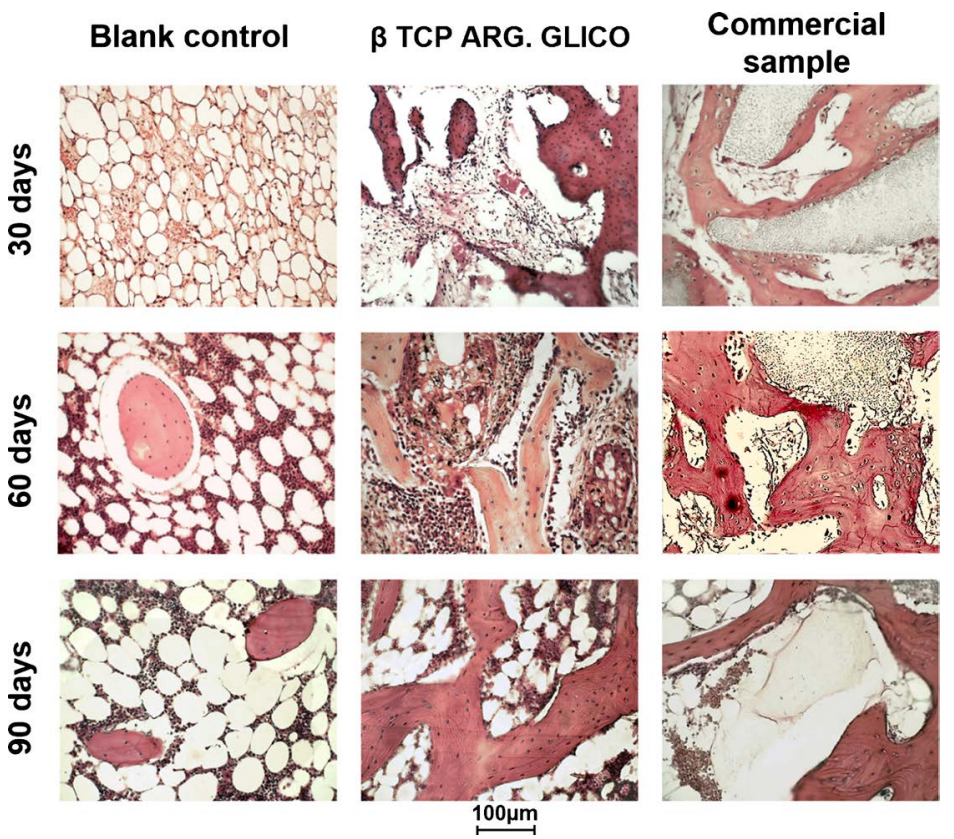

Figure 10. Histomorphometric images of the blank control, biphasic $\beta$ TCP ARG. GLICO $\beta$-TCP material presented in this work, and the commercial $\beta$-TCP at 30,60, and 90 days after implantation.

At 60 days in the control perforation for the commercial sample, hematopoietic marrow adipocytes and some isolated small elliptical trabeculae were observed with incomplete vascularization in the graft area. Vascularization of the graft, hematopoietic marrows, adipocytes, and remnants of the biomaterial was observed in intimate contact with a large number of osteoblasts, and osteocytes and trabeculae organized with lamellar bone tissue were observed for the biphasic sample presented here (Figure 10).

At 90 days, the control perforation maintained the histological characteristics observed at 60 days. For the commercial graft, trabeculae organized with lamellar bone tissue were observed and, although there were large unresorbed residual particles (size: $450 \mu \mathrm{m}$ ) without reabsorption, intimate contact of the biomaterial 

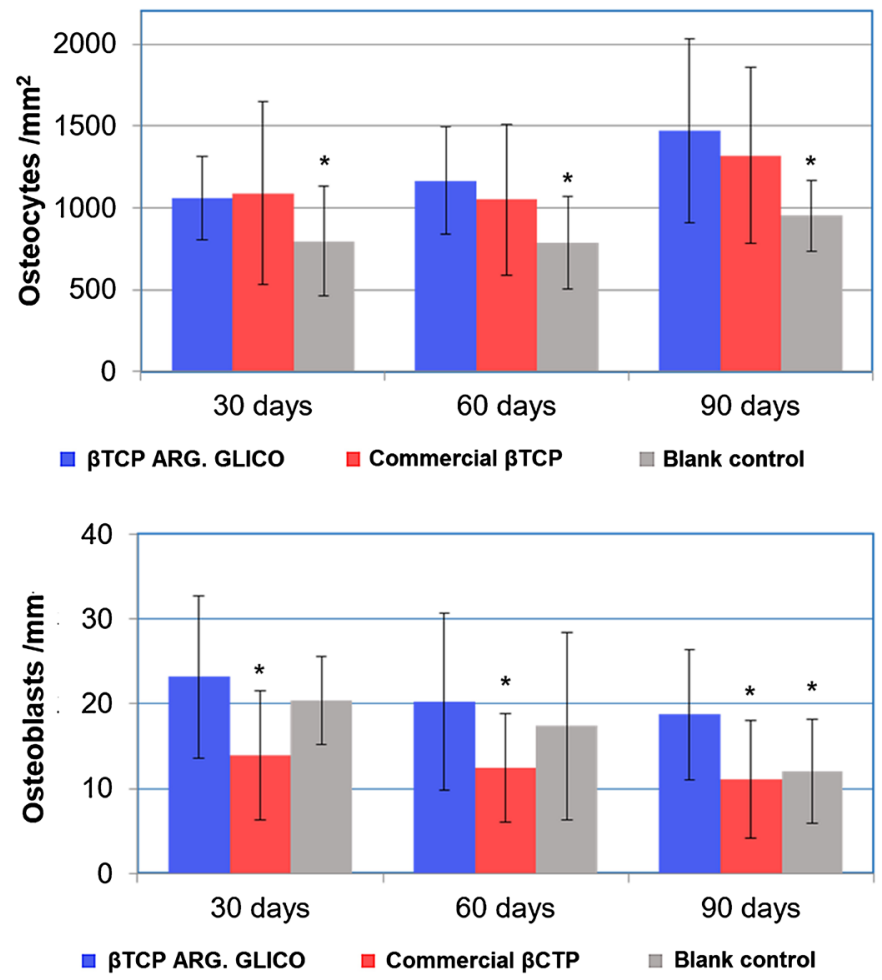

Figure 11. Values of central tendency and dispersion (mean and standard deviation) of densities of osteocytes and osteoblasts according to group and stage. Groups with significantly lower densities of osteocytes and osteoblasts were indicated with ${ }^{*}$ at each stage. When considering the density of osteocytes, the differences between groups were significant $(\mathrm{p}=0.018)$, specifically between the ARG. GLICO $\beta$-TCP and control groups ( $\mathrm{p}=$ $0.020)$, but not between both experimental groups $(\mathrm{p}=0.837)$, while the differences between stages were not significant $(\mathrm{p}=0.109)$ despite observed higher densities in all groups at 90 days. When considering the density of osteoblasts, the differences between groups were again significant $(p=0.015)$, but this time only between the test groups $(p=0.011)$, and not between the commercial $\beta$-CTP and control groups $(\mathrm{p}=0.294)$. The differences between stages were not significant $(\mathrm{p}=0.193)$, although in this case the osteoblastic activity decreased over time. Numbers of samples for each time point: $\mathrm{n}=5$ for ARG. GLICO $\beta$-TCP, $\mathrm{n}=5$ for the commercial $\beta$-TCP, and $\mathrm{n}=10$ for the control group.

with the osteoblasts of the trabecula was verified. The microcrystalline biphasic graft also organized trabeculae (lamellar bone tissue) with a large number of osteoblasts with abundant hematopoietic marrows and adipocytes, but no remnants of the biomaterial were observed.

\section{Discussion}

The particle morphology of bone substitute graft materials (visible under SEM) has a significant effect on determination of cell proliferation and adhesion, which will accelerate the start of bone tissue neoformation [54]. In this context, small domains are desirable, as they enable stronger attachment between graft materials and natural bone [54]. The biphasic ceramic, ARG. GLICO $\beta$-TCP, described in the present work presented greater solubility than the commercial material, evidenced by the inverse proportion of the calcium/phosphorous ratio [55] [56]. 
Regarding the mineral phases concentration, the composition obtained for the present material favors bone induction, since, according to the observation of other authors, bone induction occurs more quickly in samples with $\mathrm{CaPO}_{4} / \beta$-TCP ratios of around 20/80, compared with biphasic samples with higher $\mathrm{CaPO}_{4} / \beta$-TCP ratios, pure HA, and pure $\beta$-TCP [57] [58]. Graziano and Zhang demonstrated direct contact between cells and the nanometric surface of calcium phosphate ceramics by means of osteogenic differentiation (osteoinduction) [59] [60]. They also postulated that the size of the surface microstructure could be large enough to induce MSC differentiation, leading to bone tissue formation. Lower crystallinity may facilitate a higher calcium release rate, as evidenced by dissolution testing in an acid environment [61].

These results of compression tests expressed more compression resistance for the commercial sample. However, the values obtained for both materials were large enough to use as bone substitutes and were similar to those published by other authors in studies of porous scaffolds of $\beta$-TCP [62] [63] [64]. These results shown in the present work verified that the degree of purity and architecture of the scaffold (surface morphology and porosity) presented had a significant influence on the union, differentiation, and proliferation of the cells, which ultimately enabled the reabsorption of granules by macrophages and their gradual replacement by new bone. The present study determined the size of nanocrystals of the $\beta$-TCP phases, but the percentage of nanocrystals present in both materials was not measured. The use of glycolic acid as a precursor achieved a high total porosity with a large surface area (determined by the BET method) that allowed for better penetration and integration of recipient tissues.

Porosity is a main key related to bioimplants setups that stimulate bone tissue, which must have a total porosity higher than $50 \%$ with a minimum recommended pore size of $100 \mu \mathrm{m}$, corresponding to the diameter found in physiological Haversian systems in bone tissue [65] [66]. The same method to increase porosity was applied by Li et al. [67] for two commercial materials, resulting in respective values of $75 \%$ and $80 \%$. A porosity of $79 \%$ (measured by the Archimedes method) was reported by Amera et al. [58] for a sample with a $\mathrm{CaPO}_{4} / \beta \mathrm{TCP}$ ratio of 16/84. The huge difference in porosity between ARG. GLICO $\beta$-TCP (porosity: $82 \%$ ) and $\beta$-TCP Sinergy Odontit ${ }^{\circledR} \beta$-TCP (Buenos Aires, Argentina; porosity: $50 \%$ ) was a crucial factor in this work, since the greater porosity increased graft vascularization and cell proliferation, which was observed in the bone healing during in vivo studies. Therefore, the key differences found between the material presented here and the commercial graft were the higher cellularity and vascularization and less amount of biomaterials remaining in the synthesized sample compared with in the commercial graft, which has a more considerable amount of the residual biomaterial due to its lower purity and low porosity.

The high porosity observed in SEM images and high surface areas obtained can be associated with the effect of glycolic acid in the sintering process [67] [68]. A higher release of ions is favored by larger BET areas, which favors the degradation of the material while providing molecules for the new bone formation 
[69] [70]. The synthesized material had a large number of interconnections between nanopores that allowed for vascularization, with increased osteoblast proliferation and differentiation throughout scaffolding. This increased oxygen transport and the flow of nutrients, while facilitating the elimination of waste. ARG. GLICO $\beta$-TCP's high open porosity presented partial oxygen pressure inside the implant equal to outside the graft. Moreover, its architecture was closely related to the structure and morphology of the new bone tissue.

The larger microporosity and roughness of the pore wall (related with the BET area) obtained for the synthesized sample had a significant impact on the osteogenic response, since these large surface areas contributed to the adsorption of osteoinductive proteins, the exchange of ions, and the formation of apatite similar to bone tissue by dissolution and reprecipitation.

Bone regeneration in the area of critical cortical defects observed in both materials (Figure 9) confirmed the benefit of using biomaterials to fill bone defects and facilitate healing [71]-[78].

The clinical implications of this experimental work lie in the in vivo confirmation of the nanocharacteristics of the designed grafting material and the enhanced in vivo integration promoted by the nanoporosity of the material. Synthetic bone grafts should be customized to the specific site/patient requirements and adapted for the mechanical environment, in which they will function.

Future steps, including nanoindentation studies to know if there is plastic deformation on a nanometric scale, will provide additional light to the biomechanics of nanoporous $\beta$ - $\mathrm{TCP} / \mathrm{CaPO}_{4}$ mixtures.

\section{Conclusion}

In this work, a granulated bone grafting material based on $\beta$ - TCP/CaPO ${ }_{4}$ mixtures was synthesized by chemical precipitation. The biomaterial obtained was resorbable with high purity, porous, and microcrystalline, which was formed from the reaction between calcium phosphate and glycolic acid, both precursors of technical grade and low cost. This bioceramic can be used as a graft for the replacement of lost bone tissue in humans. The histological and histomorphometric study of neoformed bone tissue and the remnant of the biomaterial were carried out during the first, second, and third months after implantation in tibias from New Zealand White rabbits. The new synthesized biphasic biomaterial used industrial-grade precursors that reduced manufacturing cost, possessing advantageous physical-chemical characteristics, mechanical properties, variable porosity, and appropriate bioactivity. In addition, it presented a smaller surface microstructure with $68 \mathrm{~nm}$ nanocrystals. The crystalline domain size of $120 \mathrm{~nm}$ obtained for the commercial bone graft formed a more extensive surface microstructure. No local inflammatory response was observed in any of the periods studied both in bone implantation of the biphasic graft and in the commercial graft. Therefore, the two grafts used were biocompatible. At 90 days (sufficient time for the healing of human bone defects) in the biphasic graft, no biomaterial remains were observed. Large residual particles $(450 \mu \mathrm{m})$ were observed in the commercial graft. 


\section{Acknowledgements}

The authors gratefully acknowledge the Laboratorio de Microscopía Electrónica y Análisis for Técnicas de Rayos X (LAMARX), the Centro Atómico Bariloche and the Area de Biología Odontológica Facultad de Odontología UNC, where measurements were carried out. We also thank the bioterio of the Neuroscience Laboratory of the Faculty of Medical Sciences of the Catholic University of Cuyo where experimental research in animals was carried out.

\section{Conflicts of Interest}

The authors declare no conflicts of interest regarding the publication of this paper.

\section{References}

[1] Davies, J.E. and Hosseini, M.M. (2000) Histodinamics of Endosseous Would Healing. In: Davies, J.E., Ed., Proceedings of International Bone Engineering Workshop, Em Squared Incorporated, Toronto, 1-14.

[2] Mandalunis, P.M. (2006) Remodelación ósea. Actualiz Osteología, 2, 16-18.

[3] Parfitt, A.M., Villanueva, A.R., Foldes, J. and Rao, D.S. (1995) Relations between Histologyc Indices of Bone Formation: Implication for the Pathogenesis of Spinal Osteoporosis. Journal of Bone and Mineral Research, 10, 466-473. https://doi.org/10.1002/jbmr.5650100319

[4] Andersen, T.L., Sondergaard, T.E., Skorzynska, K.E., Dagnaes-Hansen, F., Plesner, T.L., Hauge, E.M., Plesner, T. and Delaisse, J.M. (2009) Un mecanismo físico para acoplamiento reabsorción ósea y formación de hueso humano adulto. The American Journal of Pathology, 174, 239-247. https://doi.org/10.2353/ajpath.2009.080627

[5] Fernández-Tresguerres-Hernández-Gil, I., Alobera-Gracia, M.A., Del-Canto-Pingarrón, M. and Blanco-Jerez, L. (2006) Physiological Bases of Bone Regeneration I. Histology and Physiology of Bone Tissue. Medicina Oral Patología Oral y Cirugia Bucal, 11, 47-51.

[6] Manolagas, S.C. (2000) Birth and Death of Bone Cells: Basic Regulatory Mechanisms and Implications for the Pathogenesis and Treatment of Osteoporosis. Endocrine Reviews, 21, 115-137. https://doi.org/10.1210/er.21.2.115

[7] Chen, X., Guo, J., Yuan, Y., Sun, Z., Chen, B., Tong, X., Zhang, L., Shen, C. and Zou, J. (2017) Cyclic Compression Stimulates Osteoblast Differentiation via Activation of the Wnt/ $\beta$-Catenin Signaling Pathway. Molecular Medicine Reports, 15, 2890-2896. https://doi.org/10.3892/mmr.2017.6327

[8] Shah, F.A. and Palmquist, A. (2017) Evidence That Osteocytes in Autogenous Bone Fragments Can Repair Disrupted Canalicular Networks and Connect with Osteocytes in de Novo Formed Bone on the Fragment Surface. Calcified Tissue International, 101, 321-327. https://doi.org/10.1007/s00223-017-0283-2

[9] Barrère, F., A Van Blitterswijk, C. and De Groot, K. (2006) Bone Regeneration: Molecular and Cellular Interactions with Calcium Phosphate Ceramics. International Journal of Nanomedicine, 1, 317-332.

[10] Hulbert, S.F., Bokros, J.C., Hench, L.L., Wilson, J. and Heimke, G. (1987) Ceramics in Clinical Applications, Past, Present and Future. In: Vincenzini, P., Ed., High Tech Ceramics, Elsevier Science, Amsterdam, 189-213. 
[11] De Aza, P., García-Bernal, D., Cragnolini, F., Velasquez, P. and Meseguer-Olmo, L. (2013) The Effects of $\mathrm{Ca}_{2} \mathrm{SiO}_{4}-\mathrm{Ca}_{3}\left(\mathrm{PO}_{4}\right)_{2}$ Ceramics on Adult Human Mesenchymal Stem Cell Viability, Adhesion, Proliferation, Differentiation and Function. Materials Science and Engineering C, 33, 4009-4020. https://doi.org/10.1016/j.msec.2013.05.043

[12] Zhang, J., Zhao, L., Bian, X. and Chen, G. (2018) $\mathrm{Ce}^{3+} / \mathrm{Mn}^{2+}$-Activated $\mathrm{Ca}_{7}\left(\mathrm{PO}_{4}\right)_{2}\left(\mathrm{SiO}_{4}\right)_{2}$ : Efficient Luminescent Materials for Multifunctional Applications. Optics Express, 26, A904-A914. https://doi.org/10.1364/OE.26.00A904

[13] Venkatesan, J. and Kim, S.-K. (2014) Nano-Hydroxyapatite Composite Biomaterials for Bone Tissue Engineering-A Review. Journal of Biomedical Nanotechnology, 10, 3124-3140. https://doi.org/10.1166/jbn.2014.1893

[14] Oryan, A., Alidadi, S., Moshiri, A. and Maffulli, N. (2014) Bone Regenerative Medicine: Classic Options, Novel Strategies, and Future Directions. Journal of Orthopaedic Surgery and Research, 9, 18. https://doi.org/10.1186/1749-799X-9-18

[15] Deev, R.V., Drobyshev, A.Y., Bozo, I. and Isaev, A.A. (2015) Ordinary and Activated Bone Grafts: Applied Classification and the Main Features. BioMed Research International, 2015, Article ID: 365050. https://doi.org/10.1155/2015/365050

[16] Yuan, H., Fernandes, H., Habibovic, P., De Boer, J., Barradas, A., De Ruiter, A., Walsh, W., Van Blitterswijk, C. and De Bruijn, J. (2010) Osteoinductive Ceramics as a Synthetic Alternative to Autologous Bone Grafting. Proceedings of the National Academy of Sciences of the United States of America, 107, 13614-13619. https://doi.org/10.1073/pnas.1003600107

[17] Mao, L.X., Liu, J., Zhao, J., Chang, J., Xia, L., Jiang, L., Wang, X., Lin, K. and Fang, B. (2015) Effect of Micro-Nano-Hybrid Structured Hydroxyapatite Bioceramics on Osteogenic and Cementogenic Differentiation of Human Periodontal Ligament Stem Cell via Wnt Signaling Pathway. International Journal of Nanomedicine, 10, 7031-7044. https://doi.org/10.2147/IJN.S90343

[18] Ruso, J., Sartuqui, J. and Messina, P.V. (2015) Multiscale Inorganic Hierarchically Materials: Towards an Improved Orthopaedic Regenerative Medicine. Current Topics in Medicinal Chemistry, 15, 2290-2305. https://doi.org/10.2174/1568026615666150605115610

[19] Dorozhkin, S.V. (2011) Calcio Orthophosphates: Occurrence, Properties, Biomineralization, Pathological Calcification and Biomimetic Applications. Biomaterials, 1, 121-164. https://doi.org/10.4161/biom.18790

[20] Jelusic, D., Zirk, M.L., Fienitz, T., Plancak, D., Puhar, I. and Rothamel, D. (2017) Monophasic $\beta$-TCP vs Biphasic HA/ $\beta$-TCP in Two-Stage Sinus Floor Augmentation Procedures-A Prospective Randomized Clinical Trial. Clinical Oral Implants Research, 28, 175-183. https://doi.org/10.1111/clr.12983

[21] Kini, V., Nayak, D.G., Uppoor, A.S. and Patil, S. (2016) A Clinical Evaluation of Biphasic Calcium Phosphate Alloplast with and without a Flowable Bioabsorbable Guided Tissue Regeneration Barrier in the Treatment of Mandibular Molar Class II Furcation Defects. The Journal of Contemporary Dental Practice, 17, 143-148. https://doi.org/10.5005/jp-journals-10024-1817

[22] Lim, H.-C., Kim, K.-T., Lee, J.-S., Jung, U.-W. and Choi, S.-H. (2015) In Vivo Comparative Investigation of Three Synthetic Graft Materials with Varying Compositions Processed Using Different Methods. The International Journal of Oral \& Maxillofacial Implants, 30, 1280-1286. https://doi.org/10.11607/jomi.3999

[23] Hutmacher, D.W. (2000) Scaffolds in Tissue Engineering Bone and Cartilage. Biomaterials, 21, 2529-2543. https://doi.org/10.1016/S0142-9612(00)00121-6 
[24] Karageorgiou, V. and Kaplan, D.L. (2005) Porosity of 3D Biomaterial Scaffolds and Osteogenesis. Biomaterials, 26, 5474-5491. https://doi.org/10.1016/j.biomaterials.2005.02.002

[25] Yook, S.-W., Jung, H.-D., Park, C.-H., Shin, K.-H., Koh, Y.-H., Estrin, Y. and Kim, H.-E. (2012) Reverse Freeze Casting: A New Method for Fabricating Highly Porous Titanium Scaffolds with Aligned Large Pores. Acta Biomaterials, 8, 2401-2410. https://doi.org/10.1016/j.actbio.2012.03.020

[26] Loh, Q.L. and Choong, C. (2013) Three-Dimensional Scaffolds for Tissue Engineering Applications: Role of Porosity and Pore Size. Tissue Engineering Part B: Reviews, 19, 485-502. https://doi.org/10.1089/ten.teb.2012.0437

[27] Kuboki, Y., Jin, Q. and Takita, H. (2001) Geometry of Carriers Controlling Phenotypic Expression in BMP-Induced Osteogenesis and Chondrogenesis. Journal of Bone and Joint Surgery, 83, S1-S105. https://doi.org/10.2106/00004623-200100002-00005

[28] LeGeros, R.Z. (1991) Calcium Phosphates in Oral Biology and Medicine. Monographs in Oral Science, 15, 1-201.

[29] Daculsi, G., LeGeros, R.Z., Heughebaert, M. and Barbieux, I. (1990) Formation of Carbonate-Apatite Crystals after Implantation of Calcium Phosphate Ceramics. Calcified Tissue International, 46, 20-27. https://doi.org/10.1007/BF02555820

[30] Henkel, J., Woodruff, M.A., Epari, D., Steck, R., Glatt, V., Dickinson, I.C., Choong, P., Schuetz, M.A. and Hutmacher, D.W. (2013) Bone Regeneration Based on Tissue Engineering Conceptions-A 21st Century Perspective. Bone Research, 1, 216-248. https://doi.org/10.4248/BR201303002

[31] Cheng, M.-Q., Wahafu, T., Jiang, G.-F., Liu, W., Qiao, Y.-Q., Peng, X.-C., Cheng, T., Zhang, X., He, G. and Liu, X.-Y. (2016) A Novel Open-Porous Magnesium Scaffold with Controllable Microstructures and Properties for Bone Regeneration. Scientific Reports, 6, Article No. 24134. https://doi.org/10.1038/srep24134

[32] Volkmer, E., Drosse, I., Otto, S., Stangelmayer, A., Stengele, M., Kallukalam, B., Mutschler, W. and Schieker, M. (2008) Hypoxia in Static and Dynamic 3D Culture Systems for Tissue Engineering of Bone. Tissue Engineering Part A, 14, 1331-1340. https://doi.org/10.1089/ten.tea.2007.0231

[33] Amini, A.R., Adams, U.J., Laurencin, C.T. and Nukavarapu, S. (2012) Optimally Porous and Biomechanically Compatible Scaffolds for Large-Area Bone Regeneration. Tissue Engineering Part A, 18, 1376-1388.

https://doi.org/10.1089/ten.tea.2011.0076

[34] Madden, L.R., Mortisen, D.J., Sussman, E., Dupras, S.K., Fugate, J.A., Cuy, J.L., Hauch, K.D., Laflamme, M., Murry, C.E. and Ratner, B.D. (2010) Proangiogenic Scaffolds as Functional Templates for Cardiac Tissue Engineering. Proceedings of the National Academy of Sciences of the United States of America, 107, 15211-15216. https://doi.org/10.1073/pnas.1006442107

[35] Oliviero, O., Ventre, M. and Netti, P.A. (2012) Functional Porous Hydrogels to Study Angiogenesis under the Effect of Controlled Release of Vascular Endothelial Growth Factor. Acta Biomaterials, 8, 3294-3301. https://doi.org/10.1016/j.actbio.2012.05.019

[36] Hutmacher, D.W., Schantz, J.T., Lam, C.X.F., Tan, K.C. and Lim, T.C. (2007) State of the Art and Future Directions of Scaffold-Based Bone Engineering from a Biomaterials Perspective. Journal of Tissue Engineering and Regenerative Medicine, 1, 245-260. https://doi.org/10.1002/term.24

[37] Jo, Y.J., Kim, K.H., Koo, K., Kim, T., Seol, Y., Lee, Y., Ku, Y., Chung, C. and Rhyu, I. 
(2011) Initial Adhesion of Bone Marrow Stromal Cells to Various Bone Graft Substitutes. Journal of Periodontal \& Implant Science, 41, 67-72. https://doi.org/10.5051/jpis.2011.41.2.67

[38] Fan, H., Ikoma, T., Tanaka, J. and Zhang, X. (2007) Surface Structural Biomimetics and the Osteoinduction of Calcium Phosphate Biomaterials. Journal of Nanoscience and Nanotechnology, 7, 808-813. https://doi.org/10.1166/jnn.2007.501

[39] Hung, B.P., Naved, B.A., Nyberg, E.L., Dias, M., Holmes, C., Elisseeff, J.H., Dorafshar, A.H. and Grayson, W. (2016) Three-Dimensional Printing of Bone Extracellular Matrix for Craniofacial Regeneration. ACS Biomaterials Science \& Engineering, 2, 1806-1816.

[40] Ishida, H., Haniu, H., Takeuchi, A., Ueda, K., Sano, M., Tanaka, M., Takizawa, T., Sobajima, A., Kamanaka, T. and Saito, N. (2019) In Vitro and in Vivo Evaluation of Starfish Bone-Derived $\beta$-Tricalcium Phosphate as a Bone Substitute Material. Materials, 12, 1881. https://doi.org/10.3390/ma12111881

[41] Hannink, G. and Arts, J. (2011) Bioresorbability, Porosity and Mechanical Strength of Bone Substitutes: What Is Optimal for Bone Regeneration? Injury, 42, S22-S25. https://doi.org/10.1016/j.injury.2011.06.008

[42] Villalá, M.A.G., Guirado, J.L.C., Granados, D., Limandri, S.P. and Josa, V.G. (2017) Synthesis, Chemical and Microstructural Characterization of Micro Macroporous Biphasic Calcium Phosphate Granules. X-Ray Spectrometry, 46, 237-241. https://doi.org/10.1002/xrs.2762

[43] McCanless, J.D., Jennings, L.K., Cole, J.A., Bumgardner, J.D. and Haggard, W.O. (2012) Induction of the Early Inflammatory-Mediated Cellular Responses of Fracture Healing in Vitro Using Platelet Releasate-Containing Alginate/CaPO${ }_{4}$ Biomaterials for Early Osteoarthritis Prevention. Journal of Biomedical Materials Research Part A, 100, 1107-1114. https://doi.org/10.1002/jbm.a.34038

[44] Lugo, G.J., Mazón, P., Baudin, C. and De Aza, P. (2015) Nurse's A-Phase: Synthesis and Characterization in the Binary System $\mathrm{Ca}_{2} \mathrm{SiO}_{4}-\mathrm{Ca}_{3}\left(\mathrm{PO}_{4}\right)_{2}$. Journal of the American Ceramic Society, 98, 3042-3046. https://doi.org/10.1111/jace.13747

[45] García-Páez, I.H., Carrodeguas, R.G., De Aza, A.H., Baudin, C. and Peña, P. (2014) Effect of $\mathrm{Mg}$ and $\mathrm{Si}$ Co-Substitution on Microstructure and Strength of Tricalcium Phosphate Ceramics. Journal of the Mechanical Behavior of Biomedical Materials, 30, 1-15. https://doi.org/10.1016/j.jmbbm.2013.10.011

[46] Norma UNE-EN843-5 (2006) Cerámicas técnicas avanzadas. Cerámicas monolíticas. Propiedades mecánicas a temperatura ambiente. Parte 5: Análisis estadístico. Asociación española de normalización y certificación. AENOR.

[47] Weibull, W. (1951) A Statistical Distribution Function of Wide Applicability. Journal of Applied Mechanics, 18, 292-297.

[48] Villora, J., Callejas, P., Barba, M. and Baudin, C. (2004) Statistical Analysis of the Fracture Behaviour of Porous Ceramic Raschig Rings. Journal of the European Ceramic Society, 24, 589-594. https://doi.org/10.1016/S0955-2219(03)00245-0

[49] De Aza, P., De Val, J.E.M.S., Baudin, C., Martínez, C.P.-A., Salto, A.A. and Calvo-Guirado, J.L. (2016) Retracted: Bone Neoformation of a Novel Porous Resorbable Si-Ca-P-Based Ceramic with Osteoconductive Properties: Physical and Mechanical Characterization, Histological and Histomorphometric Study. Clinical Oral Implants Research, 27, 1368-1375. https://doi.org/10.1111/clr.12745

[50] De Val, J.E.M.S., Calvo-Guirado, J.L., Delgado-Ruiz, R.A., Fernandez, M.P.R., Negri, B., Abboud, M., Martínez, I.M. and De Aza, P. (2012) Physical Properties, Mechanical Behavior, and Electron Microscopy Study of a New $\alpha$-TCP Block Graft with 
Silicon in an Animal Model. Journal of Biomedical Materials Research Part A, 100, 3446-3454. https://doi.org/10.1002/jbm.a.34259

[51] Meseguer Olmo, L.R. (1996) Study of the Bone Response of the Compound $\beta$-Tricalcium Phosphate-Collagen in the Reconstruction of Bone Defects: Experimental Model in Rabbits. Materials and Methods IV-B.2; Surgical Anesthetic Method, Publications Service University, Murcia.

[52] McCanless, J.D., Jennings, L.K., Bumgardner, J.D., Cole, J.A. and Haggard, W.O. (2012) Hematoma-Inspired Alginate/Platelet Releasate/ $\mathrm{CaPO}_{4}$ Composite: Initiation of the Inflammatory-Mediated Response Associated with Fracture Repair in Vitro and ex Vivo Injection Delivery. Journal of Materials Science: Materials in Medicine, 23, 1971-1981. https://doi.org/10.1007/s10856-012-4672-9

[53] Turner, T.M., Hall, D.J., Inoue, N., Gitelis, S., et al. (2007) Increased Bone Formation Using Calcium Sulfate-Calcium Phosphate Composite Graft. Clinical Orthopaedics and Related Research, 459, 110-117.

https://doi.org/10.1097/BLO.0b013e318059b902

[54] Webster, T. (2000) Enhanced Functions of Osteoblasts on Nanophase Ceramics. Biomaterials, 21, 1803-1810. https://doi.org/10.1016/S0142-9612(00)00075-2

[55] Chacón, V.P.G. and Habibovic, P. (2017) Deconvoluting the Bioactivity of Calcium Phosphate-Based Bone Graft Substitutes: Strategies to Understand the Role of Individual Material Properties. Advanced Healthcare Materials, 6, Article ID: 1601478. https://doi.org/10.1002/adhm.201601478

[56] Bouler, J.-M., Pilet, P., Gauthier, O. and Verron, E. (2017) Biphasic Calcium Phosphate Ceramics for Bone Reconstruction: A Review of Biological Response. Acta Biomaterials, 53, 1-12. https://doi.org/10.1016/j.actbio.2017.01.076

[57] Arinzeh, T.L., Tran, T., McAlary, J. and Daculsi, G. (2005) A Comparative Study of Biphasic Calcium Phosphate Ceramics for Human Mesenchymal Stem-Cell-Induced Bone Formation. Biomaterials, 26, 3631-3638. https://doi.org/10.1016/j.biomaterials.2004.09.035

[58] Amera, A., Abudalazez, A., Ismail, R., Razak, A., Masudi, M., Kasim, R. and Ahmad, A. (2011) Synthesis and Characterization of Porous Biphasic Calcium Phosphate Scaffold from Different Porogens for Possible Bone Tissue Engineering Applications. Science of Sintering, 43, 183-192. https://doi.org/10.2298/SOS1102183A

[59] Graziano, A., Daquino, R., Cusella de Angelis, M.G., De Francesco, F., Giordano, A., Laino, G., Piattelli, A., Traini, T., De Rosa, A. and Papaccio, G. (2008) Scaffold's Surface Geometry Significantly Affects Human Stem Cell Bone Tissue Engineering. Journal of Cellular Physiology, 214, 166-172. https://doi.org/10.1002/jcp.21175

[60] Zhang, J., Luo, X., Barbieri, D., Barradas, A., De Bruijn, J., Van Blitterswijk, C. and Yuan, H. (2014) The Size of Surface Microstructures as an Osteogenic Factor in Calcium Phosphate Ceramics. Acta Biomaterials, 10, 3254-3263.

https://doi.org/10.1016/j.actbio.2014.03.021

[61] Desterro, F.D.P.D., Sader, M.S., Soares, G.D.D.A. and Jr., G.M.V. (2014) Can Inorganic Bovine Bone Grafts Present. Brazilian Dental Journal, 25, 282-288. https://doi.org/10.1590/0103-6440201300067

[62] Furusawa, T., Minatoya, T., Okudera, T., Sakai, Y., Sato, T., Matsushima, Y. and Unuma, H. (2016) Enhancement of Mechanical Strength and in Vivo Cytocompatibility of Porous $\beta$-Tricalcium Phosphate Ceramics by Gelatin Coating. International Journal of Implant Dentistry, 2, 4. https://doi.org/10.1186/s40729-016-0037-3

[63] Gao, C., Wei, P., Feng, P., Xiao, T., Shuai, C. and Peng, S. (2015) Nano $\mathrm{SiO}_{2}$ and $\mathrm{MgO}$ Improve the Properties of Porous $\beta$-TCP Scaffolds via Advanced Manufac- 
turing Technology. International Journal of Molecular Sciences, 16, 6818-6830. https://doi.org/10.3390/ijms16046818

[64] Feng, Z., Liu, J., Shen, C., Lu, N., Zhang, Y., Yang, Y. and Qi, F. (2015) Biotin-Avidin Mediates the Binding of Adipose-Derived Stem Cells to a Porous $\beta$-Tricalcium Phosphate Scaffold: Mandibular Regeneration. Experimental and Therapeutic Medicine, 11, 737-746. https://doi.org/10.3892/etm.2015.2961

[65] Shaunak, S., Dhinsa, B.S. and Khan, W.S. (2017) The Role of 3D Modelling and Printing in Orthopaedic Tissue Engineering: A Review of the Current Literature. Current Stem Cell Research \& Therapy, 12, 225-232. https://doi.org/10.2174/1574888X11666160429122238

[66] Sarikaya, B. and Aydin, H.M. (2015) Collagen/Beta-Tricalcium Phosphate Based Synthetic Bone Grafts via Dehydrothermal Processing. BioMed Research International, 2015, Article ID: 576532. https://doi.org/10.1155/2015/576532

[67] Gauthier, O., Bouler, J.-M., Aguado, E., LeGeros, R.Z., Pilet, P. and Daculsi, G. (1999) Elaboration Conditions Influence Physicochemical Properties and in Vivo Bioactivity of Macroporous Biphasic Calcium Phosphate Ceramics. Journal of Materials Science: Materials in Electronics, 10, 199-204.

[68] Descamps, M., Hornez, J. and Leriche, A. (2007) Effects of Powder Stoichiometry on the Sintering of $\beta$-Tricalcium Phosphate. Journal of the European Ceramic Society, 27, 2401-2406. https://doi.org/10.1016/j.jeurceramsoc.2006.09.005

[69] Rodrigues, M., Natale, L.C., Arana-Chaves, V.E. and Braga, R.R. (2015) Calcium and Phosphate Release from Resin-Based Materials Containing Different Calcium Orthophosphate Nanoparticles. Journal of Biomedical Materials Research Part B: Applied Biomaterials, 103, 1670-1678. https://doi.org/10.1002/jbm.b.33327

[70] Lee, D.S., Pai, Y., Chang, S. and Kim, D. (2016) Microstructure, Physical Properties, and Bone Regeneration Effect of the Nano-Sized $\beta$-Tricalcium Phosphate Granules. Materials Science and Engineering C, 58, 971-976. https://doi.org/10.1016/j.msec.2015.09.047

[71] Egol, K.A., Nauth, A., Lee, M., Pape, H.C., Watson, J.T. and Borrelli, J. (2015) Bone Grafting: Sourcing, Timing, Strategies, and Alternatives. Journal of Orthopaedic Trauma, 29, S10-S14. https://doi.org/10.1097/BOT.0000000000000460

[72] Van Lieshout, E.M. and Alt, V. (2016) Bone Graft Substitutes and Bone Morphogenetic Proteins for Osteoporotic Fractures: What Is the Evidence? Injury, 47, S43-S46. https://doi.org/10.1016/S0020-1383(16)30011-0

[73] Cheng, G., Li, Z., Wan, Q., Lv, K., Li, D., Xing, X. and Li, Z. (2015) A Novel Animal Model Treated with Tooth Extraction to Repair the Full-Thickness Defects in the Mandible of Rabbits. Journal of Surgical Research, 194, 706-716.

https://doi.org/10.1016/j.jss.2014.11.010

[74] Chang, Y.-L., Lo, Y.-J., Feng, S.-W., Huang, Y.-C., Tsai, H.-Y., Lin, C.-T., Fan, K.-H. and Huang, H.-M. (2016) Bone Healing Improvements Using Hyaluronic Acid and Hydroxyapatite/Beta-Tricalcium Phosphate in Combination: An Animal Study. BioMed Research International, 2016, Article ID: 8301624. https://doi.org/10.1155/2016/8301624

[75] Zakaria, Z., Seman, C.N.Z.C., Buyong, Z., Sharifudin, M.A., Zulkifly, A.H. and Khalid, K.A. (2016) Comparative Study of Biomaterials Used for Spinal Fusion in a New Zealand White Rabbit Model. Sultan Qaboos University Medical Journal, 16, 422-429. https://doi.org/10.18295/squmj.2016.16.04.004

[76] Alan, H., Farahani, E., Tunik, S. and Kavak, G. (2016) The Histological Study of Osseous Regeneration Following Implantation of Various Bone Graft Biomaterials. 
Nigerian Journal of Clinical Practice, 19, 517.

https://doi.org/10.4103/1119-3077.183302

[77] Giuliani, A., Manescu, A., Mohammadi, S., Mazzoni, S., Piattelli, A., Mangano, F., Iezzi, G. and Mangano, C. (2016) Quantitative Kinetics Evaluation of Blocks versus Granules of Biphasic Calcium Phosphate Scaffolds (HA/ $\beta$-TCP 30/70) by Synchrotron Radiation X-Ray Microtomography: A Human Study. Implant Dentistry, 25, 6-15. https://doi.org/10.1097/ID.0000000000000363

[78] Calvo-Guirado, J.L., Garcés, M., Delgado-Ruiz, R.A., Fernandez, M.P.R., Ferres-Amat, E. and Romanos, G.E. (2014) Biphasic $\beta$-TCP Mixed with Silicon Increases Bone Formation in Critical Site Defects in Rabbit Calvaria. Clinical Oral Implants Research, 26, 891-897. https://doi.org/10.1111/clr.12413 